\title{
Production of Autoantibodies by Human-Human
}

\section{Hybridomas}

\author{
Y. Shoenfeld, S. C. Hsu-Lin, J. E. Gabriels, L. E. Silberstein, B. C. Furie, \\ B. Furie, B. D. Stollar, and R. S. Schwartz, Department of Medicine, New \\ England Medical Center; Department of Biochemistry and Pharmacology, \\ Tufts University School of Medicine, Boston, Massachusetts 02111
}

\begin{abstract}
A B S T R A C T Peripheral blood lymphocytes and splenocytes of patients with autoimmune disease were used to prepare human-human hybridomas that produce autoantibodies. Because exogenous immunization was not used, the hybridoma antibodies were derived from B cells that spontaneously produced autoantibodies. 108 hybrids grew from 4,254 wells (2.5\%). Optimal conditions for obtaining hybridomas with the GM 4672 myeloma line included initial growth in $2-\mathrm{ml}$ wells, the use of $44 \%$ polyethylene glycol, a mononuclear cell/GM 4672 cell ratio of 5:1, and prior stimulation of the B lymphocytes with pokeweed mitogen. Hybridoma supernatants had activity against ssDNA, platelets, and erythrocytes. The results demonstrate the feasibility of producing human-human hybridomas from lymphocytes of patients with various autoimmune diseases.
\end{abstract}

\section{INTRODUCTION}

Conventional applications of hybridoma technology require the stimulation of antibodies by immunization with heterologous or allogeneic antigens, but the technique can also apply to autoantibodies that arise without deliberate immunization. Autoantibodies that have been produced by hybridomas include those against erythrocytes (1), thymocytes (2), ribosomal RNA (3), DNA (4), and the $\mathrm{Sm}$ antigen (5). Heretofore, the method has been confined to mice with spontaneous systemic lupus erythematosus (e.g., NZB, B/W, and MRL-lpr/lpr). In our study we demonstrate the feasibility of producing human-human hybridomas that secrete autoantibodies, and we define conditions required for the derivation of stable autoantibody-producing clones from both spleen and peripheral blood lymphocytes of patients with autoimmune disease.

Received for publication 18 February 1982 and in revised form 21 April 1982.

Dr. Shoenfeld is a Fullbright Scholar.

\section{METHODS}

Human myeloma cell line. The hypoxanthine phosphoribosyl transferase - deficient, hypoxanthine - aminopterine thymidine(HAT) ${ }^{1}$-sensitive mutant line GM 4672, a subline of the GM 1500 cell developed by Croce et al. (6), was obtained from the Cell Repository, Institute of Medical Research, Camden, NJ.

Isolation of lymphocytes. Venous blood collected with preservative-free heparin was diluted 1:1 with RPMI 1640 containing $10 \mathrm{mM}$ Hepes, $200 \mathrm{mM}$ L-glutamine, $100 \mu \mathrm{g} / \mathrm{ml}$ penicillin-streptomycin, $1 \%$ pyruvate, and $0.5 \%$ nonessential amino acids (hereafter referred to as RPMI/Hepes). Spleen cells from the organ removed at splenectomy from a patient with immunothrombocytopenic purpura were prepared as a single cell suspension. Mononuclear cells from blood and spleen were harvested after gradient centrifugation with Ficoll-Hypaque and washed twice with RPMI/Hepes.

Pokeweed mitogen (PWM) stimulation. Mononuclear cells $\left(10^{6}\right)$ from either blood or spleen were incubated with a 1:100 dilution of PWM (Gibco Laboratories, Grand Island Biological Co., Grand Island, NY). After 48 h the cells were washed twice with RPMI/Hepes and prepared for fusion.

Fusion. Mononuclear cells were fused with $10^{7} \mathrm{GM} 4672$ cells in ratios of $5: 1$ and $10: 1$ by the polyethylene glycol (PEG) method (7). PEG 1540 (mol wt 1,300-1,600, J. T. Baker Chemical Co., Phillipsburg, NJ), was used at $23^{\circ} \mathrm{C}$ in concentrations of 38,44 , or $50 \%$ (vol/vol in RPMI 1640 / Hepes). The mononuclear and GM 4672 cells were copelleted by centrifugation, and $2 \mathrm{ml}$ of $38 \%$ PEG were added. The cell pellet was gently resuspended and then sedimented by centrifugation for $5 \mathrm{~min}$ at $200 \mathrm{~g}$. In the case of $44 \%$ PEG, $0.5 \mathrm{ml}$ of PEG was added to the cell pellet. The pellet was gently resuspended and then sedimented by centrifugation for $3 \mathrm{~min}$ at $300 \mathrm{~g}$. In the case of $50 \%$ PEG, $0.5 \mathrm{ml}$ of PEG was added to the cell pellet. The pellet was gently resuspended in the $0.5 \mathrm{ml}$ of PEG, and after 1 and $3 \mathrm{~min}$ it was sequentially diluted by addition of $0.5 \mathrm{ml}$ and then $1 \mathrm{ml}$ of RPMI 1640/Hepes. The cells were then spun for $5 \mathrm{~min}$ at $200 \mathrm{~g}$. After treatment of cells with PEG, the supernatants were aspirated, and the cells were resuspended in RPMI $1640 /$ Hepes containing $15 \%$ fetal calf serum. After incu-

\footnotetext{
${ }^{1}$ Abbreviations used in this paper: ELISA, enzyme-linked immunoassay; HAT, hypoxanthine, aminopterine, thymidine; PBL, peripheral blood lymphocytes; PEG, polyethylene glycol; PWM, pokeweed mitogen; TBS, tris-buffered saline.
} 
bation for $24 \mathrm{~h}\left(37^{\circ} \mathrm{C}, 5 \% \mathrm{CO}_{2}\right)$, the cells were pelleted, and the tissue culture fluid was replaced with HAT medium (8) supplemented with insulin $(0.5 \mathrm{U} / \mathrm{ml})$, oxaloacetic acid $(0.132 \mathrm{mg} / \mathrm{ml}$ ) and 5\% NCTC 109 (Microbiological Associates, Walkersville, MD). The cells were seeded into either 0.2- or $2.0-\mathrm{ml}$ wells of plastic culture plates (Costar, Data Packaging, Cambridge, MA) in a concentration of $2 \times 10^{5}$ cells/well. The HAT medium was replaced every $5 \mathrm{~d}$. 1 wk after hybrids were observed macroscopically (generally $4 \mathrm{wk}$ after fusion), feeding was continued with hypoxanthine-thymidine medium. 1 wk later, the supernatants were tested for antibody production. Positive growths were cloned by limiting dilution in medium without hypoxanthine-thymidine in $0.2-\mathrm{ml}$ wells of plastic culture plates. The cloned cells were fed every $7 \mathrm{~d}$, and growth was usually visible after 2 wk. Subsequent cell culture was performed in vertical 75ml flasks.

Autoantibody screening. Anti-DNA antibodies. An enzyme-linked immunoassay (ELISA) technique was used. Polystyrene plates with 96 flat-bottom wells (Dynatech Laboratories, Inc., Dynatech Corp., Alexandria, VA) were coated first with poly-L-lysine $(50 \mu \mathrm{g} / \mathrm{ml})$, then with calf thymus ssDNA $(2.5 \mu \mathrm{g} / \mathrm{ml})$ prepared as described (9), and finally with poly-L-glutamate $(50 \mu \mathrm{g} / \mathrm{ml})$. Hybridoma supernatant $(150 \mu \mathrm{l})$ was added to each well, and the plates were incubated for $1 \mathrm{~h}$ at room temperature. After washing with phosphate-buffered saline-Tween, $150 \mu$ l alkaline-phosphataseconjugated goat anti-human immunoglobulin (IgG+IgM) was added. Plates were then incubated for $18 \mathrm{~h}$ and washed again. Bound alkaline-phosphatase conjugate was detected by addition of $150 \mu \mathrm{l} p$-nitrophenyl phosphate $(1 \mathrm{mg} / \mathrm{ml}$ in $0.5 \mathrm{M} \mathrm{NaHCO}_{3}, 2 \mathrm{mM} \mathrm{MgCl}, \mathrm{pH} \mathrm{9.5)}$ at $23^{\circ} \mathrm{C}$. The reaction was stopped with $5 \mathrm{~N} \mathrm{NaOH}$, and optical densities were read at $405 \mathrm{~nm}$ in a Dynatech model MR580 Micro ELISA Reader.

Antiplatelet antibodies. Platelets obtained from citrated blood were fixed with $3 \%$ glutaraldehyde, washed twice with Tris-buffered saline, and stored in $60 \%$ glycerol at $-20^{\circ} \mathrm{C}$. Before use, the platelets were resuspended in 2 vol of Tris-buffered saline (TBS), sedimented at $500 \mathrm{~g}$ for $15 \mathrm{~min}$, and resuspended in TBS at a concentration of $0.5-1 \times 10^{8}$ cells $/ \mathrm{ml}$. A $100-\mu l$ aliquot of the platelet suspension was added to flat-bottom microtiter wells, and the platelets were sedimented by centrifugation at $1,000 \mathrm{~g}$ for $5 \mathrm{~min}$. After aspiration of the supernatant, $200 \mu$ l of TBS with $0.5 \%$ gelatin was added to each well and the plate was incubated at $37^{\circ} \mathrm{C}$ for $30 \mathrm{~min}$. The wells were washed thrice with TBS, hybridoma supernatant was added, and the plate was incubated at $37^{\circ} \mathrm{C}$ for $60 \mathrm{~min}$. After washing with TBS, $100 \mu \mathrm{l}$ of alkaline phosphatase-conjugated goat antihuman immunoglobulin was added. The remainder of the assay was carried out as above.

Cold agglutinin. Hybridoma culture fluid $(100 \mu \mathrm{l})$ was incubated with a $2 \%$ suspension of washed, ficin-treated, type $\mathrm{O}$ erythrocytes for $1 \mathrm{~h}$ at $4^{\circ} \mathrm{C}$. The suspensions were examined for hemagglutination.

\section{RESULTS}

Table I shows the yield of hybridomas from five fusions, four with peripheral blood lymphocytes and one with splenocytes, carried out under different conditions. Hybridomas appeared in $108 / 4,254$ wells $(2.5 \%)$, usually after $4 \mathrm{wk}$ of incubation. Maintenance of the fused cells in $2.0-\mathrm{ml}$ wells yielded hybridomas in 34 / 105 wells $(32 \%)$, whereas incubation in $0.2-\mathrm{ml}$ wells resulted in hybridomas in $74 / 4,149$ wells $(1.8 \%)$. Of the 108 hybridomas, 21 (19\%) arose from fusions done with a PEG concentration of $38 \% ; 72(67 \%)$ with a PEG concentration of $44 \%$; and 15 (14\%) with a PEG concentration of $50 \%$. A mononuclear/GM 4672 cell ratio of 5:1 produced 71 of the 108 hybridomas. Maximum yield of hybridomas $(80 / 108)$ was obtained with lymphocytes that had been stimulated with PWM for $48 \mathrm{~h}$ before fusion. The single experiment that compared spleen cells with blood lymphocytes (F2 and F6) indicated that spleen cells were no more efficient in forming hybridomas than peripheral blood lymphocytes ( 1.2 and $1.1 \%$, respectively).

Of the 108 hybridomas, 16 produced autoantibodies. All of them had the IgM isotype. Seven primary growths produced antibodies to ssDNA. All seven were cloned by limiting dilution, and in each case the procedure yielded multiple antibody-producing clones. Fig. 1A shows representative results of ELISA assays for ssDNA binding by supernatants of the cloned hybridomas. The $\operatorname{IgG}_{2} \kappa$ protein produced by GM 4672

TABLE I

Incidence of Hybridomas from Five Human Fusions under Various Conditions

\begin{tabular}{|c|c|c|c|c|c|c|c|c|c|c|c|}
\hline \multirow[b]{2}{*}{ Fusion No. } & \multirow[b]{2}{*}{ Diagnosis } & \multirow{2}{*}{$\begin{array}{l}\text { No. } \\
\text { clones }\end{array}$} & \multirow[b]{2}{*}{ 2-ml wells } & \multirow[b]{2}{*}{ 0.2-ml wells } & \multicolumn{3}{|c|}{ PEG concentration } & \multicolumn{2}{|c|}{ Cell ratio } & \multicolumn{2}{|c|}{ PWM stimulation } \\
\hline & & & & & $38 \%$ & $44 \%$ & $50 \%$ & $5: 1$ & 10:1 & with & without \\
\hline$F_{2}(\mathrm{PBL})$ & SLE + ITP & 11 & - & $11 / 900$ & 4 & 5 & 2 & 7 & 4 & 10 & 1 \\
\hline$F_{6}$ (splenocytes) & SLE + ITP & 15 & - & $15 / 1,280$ & 2 & 11 & 2 & 10 & 5 & 15 & 0 \\
\hline$F_{2}(P B L)$ & $\begin{array}{l}\text { Cold } \\
\text { agglutinin } \\
\text { disease }\end{array}$ & 39 & $7 / 36$ & $32 / 1,280$ & 7 & 27 & 5 & 30 & 9 & 31 & 8 \\
\hline \multirow{3}{*}{$\begin{array}{l}F_{1}(P B L) \\
F_{2}(P B L)\end{array}$} & Atopic allergy & 14 & $7 / 34$ & $7 / 394$ & 3 & 8 & 3 & 7 & 7 & 8 & 6 \\
\hline & Atopic allergy & 29 & $20 / 35$ & $9 / 400$ & 5 & 21 & 3 & 17 & 12 & 16 & 13 \\
\hline & & 108 & $34 / 105$ & $74 / 4,254$ & 21 & 72 & 15 & 71 & 37 & 80 & 28 \\
\hline
\end{tabular}




\section{$A$}

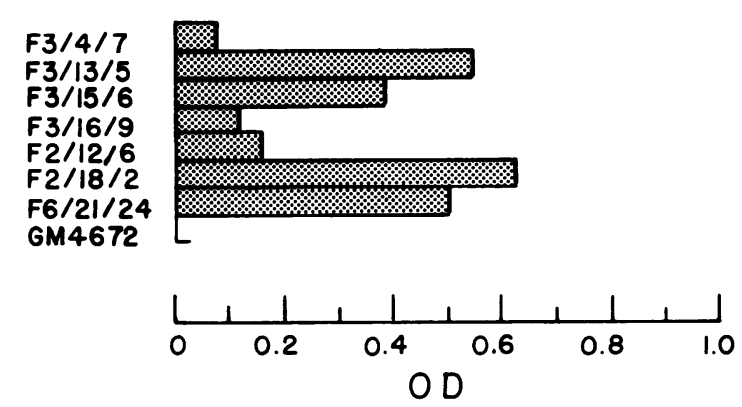

$B$
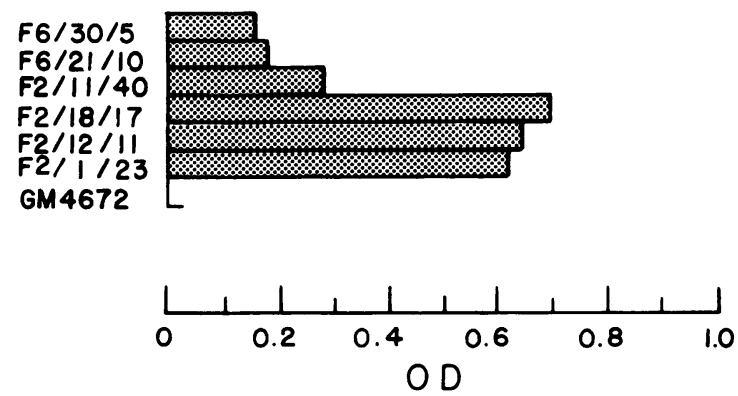

FIGURE 1 Results of direct binding ELISA assays of supernatants from representative cloned human-human hybridomas. (A) Binding to ssDNA; (B) binding to platelets.

cells failed to bind to ssDNA. Preliminary results of direct binding and competitive immunoassays (data not shown) indicated that all clones derived from a single primary growth gave identical or similar patterns of reactivity. Therefore, the primary growths were probably derived from single hybridomas.

Six primary wells contained antiplatelet activity and were also cloned by limiting dilutions. That procedure yielded 310 clones, 37 of which produced plateletbinding antibodies (Fig. 1B). The supernatants of the GM 4672 line had no antibody binding activity with platelets, nor did human-human hybrids derived from lymphocytes from a patient without autoimmune thrombocytopenia. As a positive control for the assay, human serum with anti-PL ${ }^{A}$ antibodies contained antiplatelet activity, whereas normal serum had no activity.

Seven primary growths from the patient with cold agglutinin disease (F3) produced cold agglutinins. Limiting dilutions yielded 46 clones, of which 14 were positive for cold agglutinins. The supernatants of those clones were active at $4^{\circ} \mathrm{C}$, but not at $27^{\circ}$ or $37^{\circ} \mathrm{C}$, and reactivity was revealed only with ficin-treated erythrocytes.

All of the cloned autoantibody-producing hybridomas have been passed in tissue culture repeatedly.
RPMI $1640 /$ Hepes with $10 \%$ fetal calf serum has been used throughout. The oldest line has been passed for $7 \mathrm{mo}$, and it remains stable. The other lines also continue to produce autoantibodies except for $7 / 8$ of the cold-agglutinin producing lines, which lost their ability to produce antierythrocyte antibodies. Passage in $75-\mathrm{ml}$ or $150-\mathrm{ml}$ vertical flasks has been done routinely. In such flasks the hybridomas are visible as nonadherent, macroscopic colonies, which form a carpet on the floor of the culture vessel.

\section{DISCUSSION}

Our results demonstrate the feasibility of producing autoantibodies in tissue culture by means of humanhuman hybridomas. The GM 4672 cells we used are Epstein Barr nuclear antigen-negative, ${ }^{2}$ and it is therefore unlikely that the clones we derived were Epstein Barr virus-transformed cells instead of hybridomas. Results with the GM 4672 line differ quantitatively from those obtained with mouse-mouse hybridomas. For instance, in the case of the hybridomas derived from spleen cells of MRL-lpr/lpr mice and the MPC11 myeloma, the frequency of hybridomas ranged from 26 to $45 \%$ (4). By contrast, the corresponding figure in our experiments was $2.5 \%$. Nevertheless, of 65 hybridomas obtained from the three human subjects with autoimmunity, the frequency of autoantibodyproducing hybridomas was $16 / 65(25 \%)$, a figure that compares favorably with the proportion in MRL-lpr/ $l p r$ mice $(9-58 \%$ in various experiments (4)). The amount of autoantibody produced by the human-human hybridomas ranged from 1 to $15 \mu \mathrm{ggM} / \mathrm{ml}$ (data not shown), whereas mouse-mouse hybridomas usually secrete 50-100 $\mu \mathrm{g}$ autoantibody $/ \mathrm{ml}$. Optimal conditions for obtaining hybridomas with the GM 4672 line include initial growth in $2.0-\mathrm{ml}$ wells, the use of $44 \%$ PEG, a mononuclear cell/GM 4672 cell ratio of $5: 1$, and prior stimulation of the lymphocytes with PWM. The latter step, we believe, favors the fusion of autoantibody-forming B lymphocytes with GM 4672 cells. A PEG concentration of $50 \%$ was apparently toxic to some cultures, and we have abandoned its use. The difference between 44 and 38\% PEG may not be statistically significant. Use of $2.0-\mathrm{ml}$ wells may be advantageous by providing a relatively large surface area for growth of the hybridomas. In our experience, the ELISA technique readily measures the relatively low yield of autoantibody from human-human hybridomas. Moreover, we have found that cloned humanhuman hybridomas grow well in vertical 150 -ml flasks, and by this means we have harvested as much as 600 $\mathrm{ml}$ of autoantibody-containing tissue culture fluid

\footnotetext{
${ }^{2}$ Thorley-Lawson, D. Personal communication.
} 
from each clone. Affinity purification on DNA-Sepharose columns of fluids that contain anti-DNA antibodies can thus yield amounts of monoclonal autoantibody that are adequate for extensive analyses (unpublished observations). Thus far, our attempts to grow human hybridomas in nude mice have been unsuccessful.

Hybridoma technology is a means of obtaining pure monoclonal autoantibodies and it has been highly effective in murine systems. The present results indicate that a similar approach is possible with human autoantibodies. These monoclonal antibodies should greatly facilitate studies of the antigen specificity and the structure of the combining site of antibodies produced in SLE and other autoimmune disorders. The technique may also find applications in the study of allergic diseases that are mediated by immunoglobulins.

\section{ACKNOWLEDGMENTS}

We thank Dr. Ross Rocklin for allowing us to study two of his patients.

This work was supported in part by National Institutes of Health grants AM27232, HL18834, and HL21543.

\section{REFERENCES}

1. DeHeer, D. H., J. M. Pages, and A. E. Bussard. 1980. Specificity of anti-erythrocyte autoantibodies secreted by a NZB-derived hybridoma and NZB peritoneal cells. Cell. Immunol. 49: 135-141.

2. Klotz, J. L., M. L. Phillips, M. M. Miller, and R. L. Teplitz. 1981. Monoclonal autoantibody production by hybrid cell lines. Clin. Immunol. Immunpathol. 18: 368-374.

3. Eilat, D., R. Asofsky, and R. Laskov. 1980. A hybridoma from an autoimmune NZB/NZW mouse producing monoclonal antibody to ribosomal-RNA. J. Immunol. 124: 766-768.

4. Andrzejewski, C., Jr., B. D. Stollar, T. N. Lalor, and R. S. Schwartz. 1980. Hybridoma autoantibodies to DNA. J. Immunol. 124: 1499-1502.

5. Lerner, E. A., M. R. Lerner, C. A. Janeway, Jr., and J. A. Steitz. 1981. Monoclonal antibodies to nucleic acidcontaining cellular constituents: probes for molecular biology and autoimmune disease. Proc. Natl. Acad. Sci. U.S.A. 78: 2737.

6. Croce, C. M., A. Linnenback, W. Hall, Z. Steplewski, and H. Koprowski. 1980. Production of human hybridomas secreting antibodies to measles virus. Nature (Lond.). 288: 488-491.

7. Gefter, M. L., D. H. Margulies, and M. D. Scharff. 1977. A simple method for polyethylene glycol-promoted hybridization of mouse myeloma cells. Somatic Cell Genet. 3: 231-238.

8. Littlefield, J. W. 1964. Selection of hybrids from matings of fibroblasts in vitro and their presumed recombinants. Science (Wash. DC). 145: 709-710.

9. Stollar, B. D. 1977. Quantitative microcomplement fixation and radioactive antigen binding assays for measuring anti-DNA antibodies. Ann. Rheum. Dis. 36 (Suppl.): 102-107. 